\title{
DISTRIBUSI SPASIO -TEMPORAL NITROGEN DI DAERAH TANGKAPAN AIR DANAU TONDANO PROVINSI SULAWESI UTARA
}

\author{
Sofia Wantasen, Joudie N. Luntungan \\ Fakultas Pertanian, Universitas Sam Ratulangi Manado \\ Email: swantasen@yahoo.co.id ; jnluntungan@yahoo.com
}

\begin{abstract}
The spatio temporal distribution of nitrogen in catchment area of Lake Tondano was important to investigate because agricultural residue comes from the catchment potentially decreased water quality in Lake Tondano. The purpose of this study was to examine the distribution of nitrogen spatially and temporally in the catchment area of Lake Tondano. The study was conducted in the field and laboratory. Water quality sampling conducted by using composite sampling on the rivers, lake Tondano and outlet of irrigation channels. The data collected was the total nitrogen, nitrate, ammonia in 2001, 2008 and 2014. Data were analyzed using Graph Method and Spatial Analysis.

The results showed that the distribution of total nitrogen that has a high concentration found in the outlet streams and irrigation canals outlet. High nitrate accumulates in the outlet of Lake Tondano. Nitrate concentration can be divided into 9 (nine) classes, namely concentration of 0.100 to $0.211 \mathrm{mg} / \mathrm{l} ; 0.211$ to $0.322 \mathrm{mg} / \mathrm{l} ; 0.322$ to $0.433 \mathrm{mg} / \mathrm{l} ; 0.433$ to $0.544 \mathrm{mg} / \mathrm{l} ;$ From 0.544 to $0.655 \mathrm{mg} / \mathrm{l}$; From 0.655 to $0.766 \mathrm{mg} / \mathrm{l} ; 0.766$ to $0.877 \mathrm{mg} / \mathrm{l}$; 0.877 to $0.988 \mathrm{mg} / \mathrm{l}$; and $0,988-1,100 \mathrm{mg} / \mathrm{l}$. Ammonia, spatially spread evenly on the surface of Lake Tondano. Ammonia concentration can be divided into 9 (nine) class is a class that has a concentration of 0.000 to $0.064 \mathrm{mg} / \mathrm{l}$; From 0.064 to $0.129 \mathrm{mg} / \mathrm{l} ; 0.129$ to $0.193 \mathrm{mg} / \mathrm{l} ;$ From 0.193 to $0.258 \mathrm{mg} / \mathrm{l} ; 0.258$ to $0.322 \mathrm{mg} / \mathrm{l} ; 0.322$ to $0.387 \mathrm{mg} / \mathrm{l} ;$ From 0.387 to $0.451 \mathrm{mg} / \mathrm{l} ; 0.451$ to $0.516 \mathrm{mg} / \mathrm{l}$; and from 0.516 to $0.580 \mathrm{mg} / \mathrm{l}$. Concentrations of nitrate and ammonia fluctuated from year to year of observation. This was influenced by fertilization in rice fields.
\end{abstract}

Keywords; Spatio temporal distribution, nitrogen, Catchment area of Lake Tondano

\begin{abstract}
Abstrak
Daerah tangkapan air Danau Tondano menjadi penting untuk diteliti dalam aspek distribusi spasio temporal nitrogen karena residu limbah pertanian dari daerah ini berpotensi terhadap penurunan kualitas air di Danau Tondano. Tujuan penelitian ini adalah untuk mengkaji distribusi nitrogen secara spasial dan temporal di Daerah Tangkapan Air Danau Tondano. Penelitian dilakukan di lapang dan laboratorium. Pengambilan sampel kualitas air dilakukan dengan menggunakan metode composite sampling di Sungai, Danau Tondano dan outlet saluran irigasi. Data yang dikumpulkan adalah nitrogen total, nitrat, ammonia pada tahun 2001, 2008, dan 2014. Analisis data menggunakan Metode Grafik dan Analisis Spasial.

Hasil penelitian menunjukkan bahwa distribusi nitrogen total yang memiliki konsentrasi tinggi terdapat di outlet sungai dan outlet saluran irigasi. Nitrat terakumulasi tinggi di outlet Danau Tondano. Konsentrasi Nitrat dapat dibedakan dalam 9 (Sembilan) kelas yaitu
\end{abstract}


konsentrasi 0,100-0,211 mg/l ; 0,211-0,322 mg/l ; 0,322-0,433 mg/l ; 0,433-0,544 mg/l ; 0,544-0,655 $\mathrm{mg} / \mathrm{l} ; 0,655-0,766 \mathrm{mg} / \mathrm{l} ; 0,766-0,877 \mathrm{mg} / \mathrm{l} ; 0,877-0,988 \mathrm{mg} / \mathrm{l}$; dan 0,988- 1,100 mg/l. Ammonia, secara spasial tersebar merata di permukaan Danau Tondano. Konsentrasi Ammonia dapat dibedakan dalam 9 (sembilan) kelas yaitu kelas yang memiliki konsentrasi 0,000-0,064 mg/l ; 0,064-0,129 mg/l ; 0,129-0,193 mg/l ; 0,193-0,258 mg/l ; 0,258-0,322 mg/l ; 0,322-0,387 mg/l ; $0,387-0,451 \mathrm{mg} / \mathrm{l} ; 0,451-0,516 \mathrm{mg} / \mathrm{l}$; dan 0,516-0,580 mg/l. Secara temporal konsentrasi nitrat dan ammonia berfluktuasi dari tahun ke tahun pengamatan. Hal ini dipengaruhi oleh kegiatan pemupukan pada areal persawahan.

Kata kunci; Distribusi spasio temporal, nitrogen, Daerah Tangkapan Air Danau Tondano

\section{Pendahuluan}

Daerah Aliran Sungai adalah wilayah daratan yang secara topografi dibatasi oleh punggungpunggung gunung yang menampung dan menyimpan air hujan untuk kemudian menyalurkannya ke laut melalui sungai utama. Daerah Tangkapan Air (DTA) merupakan suatu ekosistem dengan unsur utamanya terdiri atas sumberdaya alam (tanah, air, dan vegetasi) dan sumberdaya manusia sebagai pemanfaat sumberdaya alam (Asdak, 2004).

Kondisi fisik dan lingkungan DTA Danau Tondano menjadi penting untuk diteliti dalam aspek distribusi nitrogen baik secara spasial maupun temporal, mengingat kegiatan pertanian di DTA ini yang tidak terlepas juga dengan kegiatan pemupukan terutama penggunaan Pupuk Nitrogen. Air yang masuk ke Danau Tondano antara lain berasal outlet irigasi dan empat sungai yaitu Sungai Panasen, Ranowangko, Saluwangko dan Mawalelong/Leleko dan keluar dari Danau Tondano menjadi aliran Sungai Tondano melintasi Kota Tondano dan Manado menuju Laut Sulawesi.

Permasalahan utama di DTA ini adalah residu limbah pertanian. Residu limbah pertanian dominan berasal dari sisa hara yang tercuci (leaching) saat pemupukan pada aktivitas pertanian. Sekitar $77 \%$ DTA ini digunakan untuk lahan budidaya pertanian intensif, dan sisanya berupa hutan, permukiman, rawa dan solfatara (Luntungan, 2014). Aktivitas manusia yang memanfaatkan danau bertambah dengan semakin banyaknya pembudidaya ikan dengan sistem tiang pancang/karamba jaring apung. Keadaan ini membuat penurunan kualitas air Danau Tondano semakin meningkat karena nutrien terus bertambah dan proses eutrofikasi lebih dipercepat yang selanjutnya berpotensi mengancam ekosistem Danau Tondano. Peraturan Pemerintah Republik Indonesia Nomor 26 Tahun 2008 tentang Rencana
Tata Ruang Wilayah Nasional (RTRWN), DAS Tondano termasuk di dalamnya DTA Danau Tondano ditetapkan sebagai:

1. Kawasan Strategis Nasional dari sudut kepentingan fungsi dan daya dukung lingkungan hidup (Lampiran X), dan

2. Wilayah Sungai Strategis Nasional (Lampiran VI)

Kawasan Strategis Nasional adalah dilihat dari sudut kepentingan fungsi dan daya dukung lingkungan hidup ditetapkan dengan kriteria :

a. merupakan tempat perlindungan keanekaragaman hayati ;

b. merupakan aset nasional berupa kawasan lindung yang ditetapkan bagi perlindungan ekosistem, flora dan/atau fauna yang hampir punah atau diperkirakan akan punah yang harus dilindungi dan/atau dilestarikan ;

c. memberikan perlindungan keseimbangan tata guna air yang setiap tahun berpeluang menimbulkan kerugian negara ;

d. memberikan perlindungan terhadap keseimbangan iklim makro ;

e. menuntut prioritas tinggi peningkatan kualitas lingkungan hidup.

f. rawan bencana alam nasional ; atau

g. sangat menentukan dalam perubahan rona alam dan mempunyai dampak luas terhadap kelangsungan kehidupan.

Wilayah Sungai Strategis Nasional ditetapkan dengan kriteria :

a. melayani kawasan strategis nasional, PKN, atau kawasan andalan;

b. melayani paling sedikit 1 (satu) daerah irigasi yang luasnya lebih besar atau sama dengan 10.000 (sepuluh ribu) hektar; dan /atau

c. memiliki dampak negatif akibat daya rusak air terhadap pertumbuhan ekonomi yang 
mengakibatkan tingkat kerugian ekonomi paling sedikit $1 \%$ (satu persen) dari produk domestik regional bruto (PDRB) provinsi.

Nitrogen merupakan unsur hara makro yang dibutuhkan tanaman padi pada tahap vegetatif aktif. Nitrogen tersebut diperoleh dari pupuk nitrogen seperti Urea dengan rumus kimia $\mathrm{NH}_{2} \mathrm{CONH}_{2}$. Pentingnya unsur nitrogen ini adalah berkaitan dengan unsur esensial yang berhubungan dengan khlorofil (Yoshida, 1981). Unsur nitrogen menjadi faktor pembatas terhadap pertumbuhan tanaman dan akan mempengaruhi produksi. Apabila unsur ini tidak tersedia maka berakibat pada penurunan nilai produksi. Pupuk nitrogen diserap tanaman dalam bentuk nitrat dan ammonium. Nitrat $\left(\mathrm{NO}_{3}^{-}\right)$yang berlebihan akan hilang ke badan air mengalami residu di lingkungan yaitu di saluran irigasi dan badan air yang pada akhirnya dapat menyebabkan penurunan kualitas air (Elmi et al., 2004).

Kehilangan nitrogen melalui Proses Denitrifikasi akibat aplikasi pemupukan nitrogen telah diperoleh data kisaran dari 9,5\% hingga 22\%. Potensial hilangnya nitrogen ke lingkungan dalam bentuk yang lain adalah ammonia $\left(\mathrm{NH}_{3}\right)$ Volatilization dari permukaan tanah (Cossey et al., 2002). Cara pemberian pupuk nitrogen mempengaruhi hilangnya nitrogen ke lingkungan berupa penguapan, dan pencucian, sehingga nitrogen yang dimanfaatkan tanaman berkurang (Palimbani, 2007).

Bentuk-bentuk transformasi nitrogen di lingkungan adalah nitrifikasi, nitrate reduction dan denitrifikasi (Manahan, 2005 ; Wiederholt R \& B. Johnson, 2005). Apabila kondisi dengan ketersediaan oksigen (tersedianya electron acceptor) maka akan terurai dan oleh bakteri akan dioksidasi menjadi nitrat di dalam bahan organik.

Nitrat $\left(\mathrm{NO}_{3}^{-}\right)$adalah nutrien yang pada kadar berlebihan, dapat menyebabkan penurunan kualitas air suatu badan air. Nitrat dapat digunakan untuk mengelompokkan tingkat kesuburan perairan. Perairan Oligotrofik memiliki kadar Nitrat antara 0-1 $\mathrm{mg} /$ liter, perairan Mesotrofik memiliki kadar Nitrat antara $1-5 \mathrm{mg} /$ liter, dan perairan Eutrofik memiliki kadar nitrat berkisar antara 5-50 mg/liter (Arthana, 2006).

Aktivitas pertanian intensif di DTA Tondano telah berlangsung bertahun-tahun dan menghasilkan residu limbah pertanian yang berpotensi menurunkan kualitas air di Danau Tondano. Distribusi secara spasial dan temporal residu limbah pertanian terutama yang berasal dari pemupukan nitrogen perlu diketahui untuk tindaklanjut pengelolaan lingkungan. Penelitian ini bertujuan untuk mengkaji distribusi nitrogen secara spasial dan temporal di Daerah Tangkapan Air Danau Tondano.

\section{Metodologi}

\subsection{Bahan dan Alat Penelitian}

Peralatan utama yang digunakan dalam penelitian ini adalah alat pengambilan sampel air : water sampler, ice box, GPS, $\mathrm{pH}$ meter, termometer air, dan spectrophotometer: Peralatan lainnya berupa alat yang digunakan untuk analisis konsentrasi nitrogen total, nitrat, dan ammonia. Bahan penelitian adalah Peta Rupa bumi Indonesia skala 1:50.000 dan data-data spasial lainnya serta bahan aquadest, tissue dan alat tulis menulis.

\subsection{Teknik Pengumpulan Data}

Data nitrogen total diperoleh dari hasil penelitian JICA, 2001. Pengambilan data kualitas air (nitrat dan ammonia) dilakukan dengan menggunakan metode composite sampling dan mengacu pada APHA (2005). Lokasi pengambilan sampel air adalah Sungai, Danau Tondano dan outlet saluran irigasi. Data yang dikumpulkan adalah data nitrogen total, nitrat, ammonia data tahun 2001, 2008, dan 2014.

\subsection{Analisis data}

Analisis data menggunakan Metode Grafik dan Analisis Spasial.

\section{Hasil dan Pembahasan}

Distribusi spasial nitrogen total konsentrasi tinggi terdapat di outlet sungai dan outlet saluran irigasi (Gambar 1). Lokasi-lokasi tersebut terdapat di bagian selatan Danau Tondano, bagian barat dan di bagian timur Danau Tondano. Bagian sebelah selatan Danau Tondano terdapat 3 (tiga) sungai yaitu Sungai Panasen, Sungai Ranoweleng dan Sungai Saluwangko yang bermuara di Danau Tondano. Hamparan persawahan yang luas, memiliki saluran irigasi yang bermuara di Danau Tondano menjadi inlet Danau Tondano. Konsentrasi nitrogen total di Danau Tondano berkisar antara 1,11 mg/l-3,77 mg/l. Nitrat adalah salah satu bentuk nitrogen yang keberadaannya ditentukan oleh proses nitrifikasi. 
Sofia Wantasen, dkk. : Distribusi Spasio-Temporal Nitrogen di Daerah Tangkapan Air Danau .....

Senyawa nitrogen dalam bentuk nitrat dapat berasal dari limbah pertanian, limbah domestik (tinja/ air seni manusia, hewan) dan sisa tanaman/ serasah.

\section{Nitrat di Permukaan Danau Tondano :}

Pola penyebaran spasial nitrat di permukaan Danau Tondano, terlihat bahwa konsentrasi Nitrat tertinggi adalah terakumulasi di outlet Danau Tondano. Hal ini menandakan bahwa senyawa nitrat larut dan hanyut terbawa arus. Peta distribusi spasial nitrat di permukaan Danau Tondano dapat dilihat pada Gambar 2.

Berdasarkan konsentrasinya maka distribusi nitrat di permukaan Danau Tondano terdapat dalam 9 (sembilan) kelas yaitu kelas yang memiliki konsentrasi 0,100-0,211 mg/l ; 0,211-0,322 mg/l ; 0,3220,433 mg/l ;0,433-0,544 mg/l ;0,544-0,655 mg/l ;0,655-

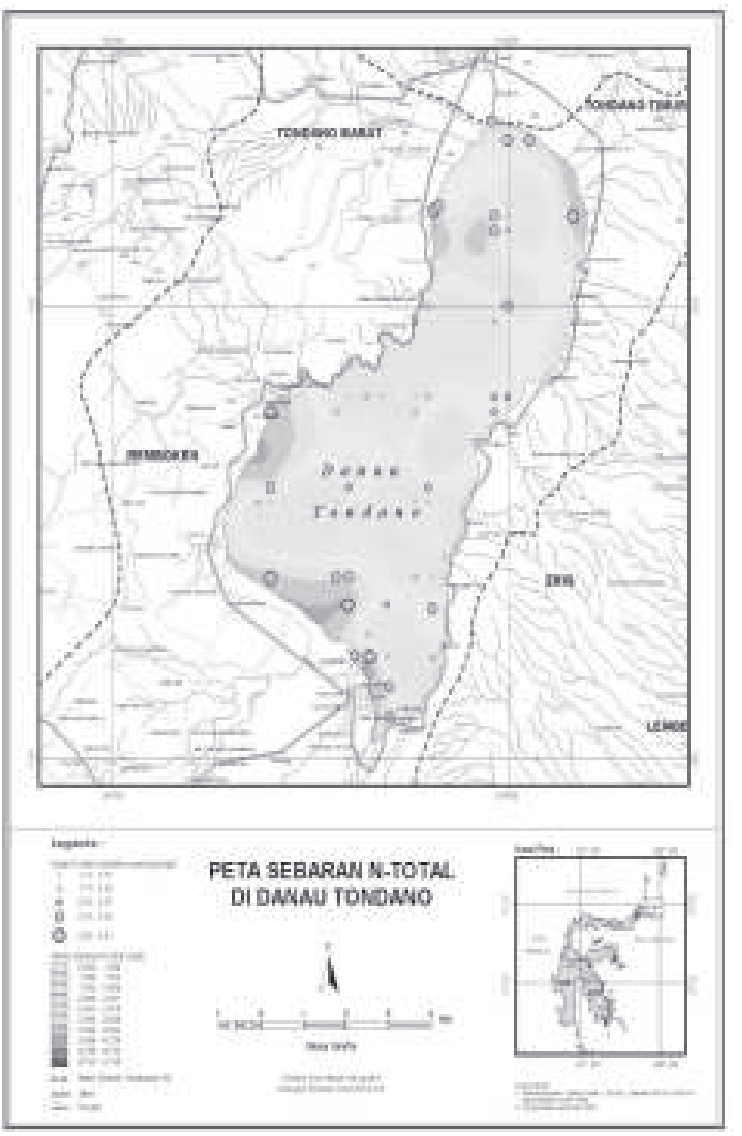

Gambar 1.

Peta Distribusi Spasial Nitrogen Total di permukaan Danau Tondano
0,766 mg/l ;0,766-0,877 mg/l ;0,877-0,988 mg/l ; 0,988$1,100 \mathrm{mg} / \mathrm{l}$.

Ammonia di Permukaan Danau Tondano :

Pola penyebaran ammonia di permukaan Danau Tondano dapat dilihat pada Gambar 3, menunjukan bahwa senyawa ammonia menyebar secara merata di permukaan Danau Tondano. Ammonia adalah merupakan bentuk intermediate dari nitrogen. Nitrogen akan terbawa air masuk ke saluran drainase, ke sungai dan selanjutnya masuk ke Danau Tondano.

Sebaran Ammonia di permukaan Danau Tondano terdapat dalam 9 (sembilan) kelas yaitu konsentrasi 0,000-0,064 mg/l ; 0,064-0,129 mg/l ; 0,129$0,193 \mathrm{mg} / \mathrm{l} ; 0,193-0,258 \mathrm{mg} / \mathrm{l} ; 0,258-0,322 \mathrm{mg} / \mathrm{l}$; 0,322$0,387 \mathrm{mg} / \mathrm{l} ; 0,387-0,451 \mathrm{mg} / \mathrm{l} ; 0,451-0,516 \mathrm{mg} / \mathrm{l} ; 0,516-$ $0,580 \mathrm{mg} / \mathrm{l}$. Senyawa ammonia lebih banyak

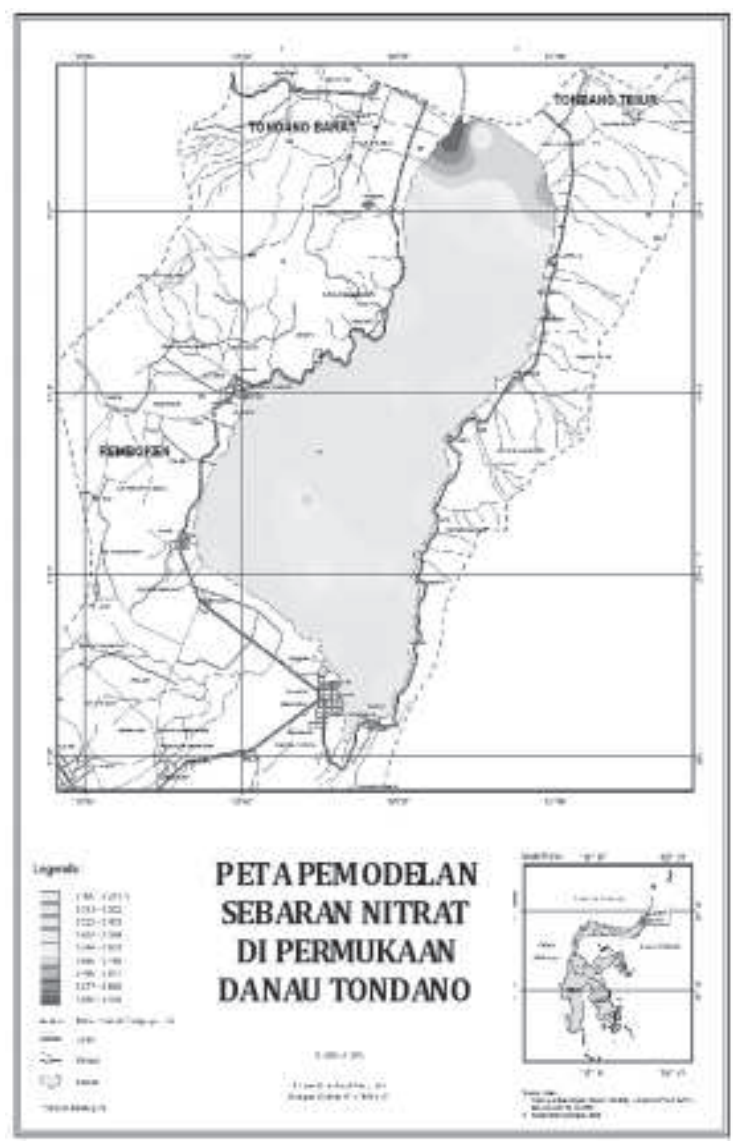

Gambar 2.

Peta Distribusi Spasial Nitrat di Permukaan Danau Tondano 


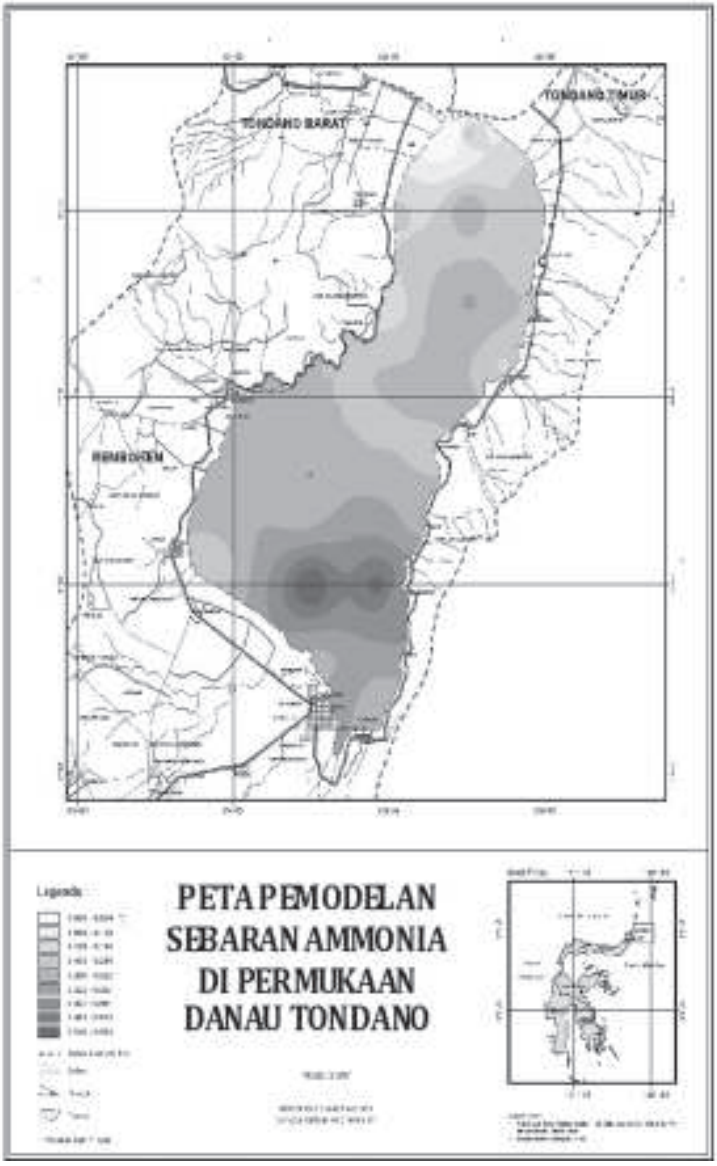

Gambar 3.

Peta Distribusi Spasial Ammonia di Permukaan Danau Tondano

terkonsentrasi di outlet sungai yang menjadi inlet Danau Tondano. Bagian selatan Danau Tondano terdapat 3 (tiga) sungai yang menjadi inlet Danau Tondano.

Secara temporal konsentrasi nitrat, dan ammonia di outlet saluran irigasi dan sungai yang menjadi inlet Danau Tondano bagian barat (Data Tahun 2008 dan 2014) dapat dilihat pada Gambar 4.

Data tahun 2008 konsentrasi nitrat berkisar antara 1,33-12,2 mg/l sedangkan data tahun 2014 konsentrasi nitrat $0,322-0,679 \mathrm{mg} / 1$. Konsentrasi ammonia 0,01-0,86 (tahun 2008) dibandingkan dengan data tahun 2014 konsentrasi ammonia $0,02 \mathrm{mg} / \mathrm{l}$. Data yang disajikan pada Gambar 4 menunjukkan bahwa terjadi penurunan residu nitrat, dan ammonia di outlet saluran irigasi Leput 2, Sungai Tougela 3, Sungai

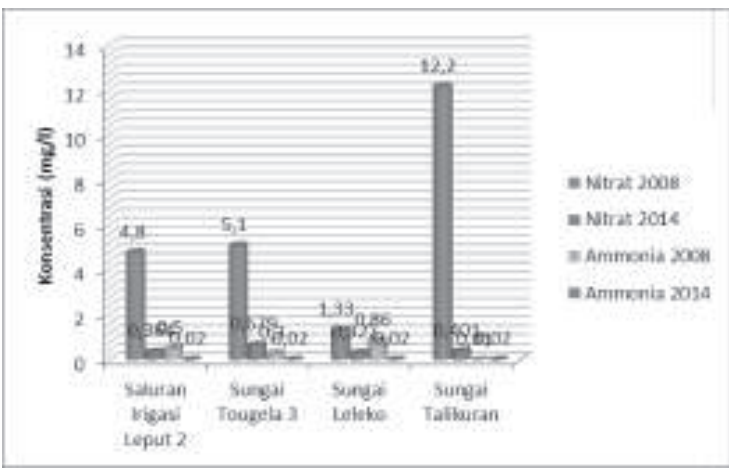

Gambar 4.

Konsentrasi Nitrat dan Ammonia di Outlet Saluran Irigasi dan Sungai Bagian Barat Danau Tondano

(Data Tahun 2008 dan 2014)

Leleko dan Sungai Talikuran hal tersebut dipengaruhi oleh kondisi tanaman dalam masa pertumbuhan vegetatif aktif (pengukuran 2008) terkait dengan pemupukan aktif. dan masa generatif (pengukuran 2014).

Demikian halnya dengan konsentrasi nitrat, ammonia di Outlet Saluran Irigasi dan sungai bagian selatan Danau Tondano (Gambar 5).

Wilayah selatan Danau Tondano didominasi persawahan dengan luas 2.924 ha atau sekitar $28 \%$ dari luas DTA ini (Luntungan, 2014). Sawah adalah lahan budidaya pertanian yang biasanya ditanami padi, yang mendapat air pengairan teknis ataupun non teknis. Lahan berpengairan teknis umumnya ditanami padi secara terus menerus atau dua bahkan tiga kali dalam setahun, sedangkan yang tidak berpeng-airan teknis hanya satu kali dalam setahun dan pada musim kering lahan ini ditanami palawija seperti tomat, jagung, kacang merah dan kacang tanah. Sawah banyak dijum-pai di sekitar sungai.

Data konsentrasi nitrat berkisar antara 11,30$18,4 \mathrm{mg} / \mathrm{l}$ (2008) sedangkan data tahun 2014 konsentrasi nitrat $0,05-1,24 \mathrm{mg} / \mathrm{l}$. Konsentrasi ammonia 0,01- 1,2 (tahun 2008) dibandingkan dengan data tahun 2014 konsentrasi ammnoia $0,02 \mathrm{mg} / \mathrm{l}$.

Data tahun 2008 konsentrasi nitrat berkisar antara 0,02- 0,7 mg/l sedangkan data tahun 2014 konsentrasi nitrat $0,044-0,812 \mathrm{mg} / \mathrm{l}$. Konsentrasi ammonia 0,1-0,4 (tahun 2008) dibandingkan dengan data tahun 2014 konsentrasi ammnoia 0,02 mg/l. Data yang terdapat pada Gambar 6 menunjukkan bahwa konsentrasi nitrat di Sungai Tounipus 2 pada 


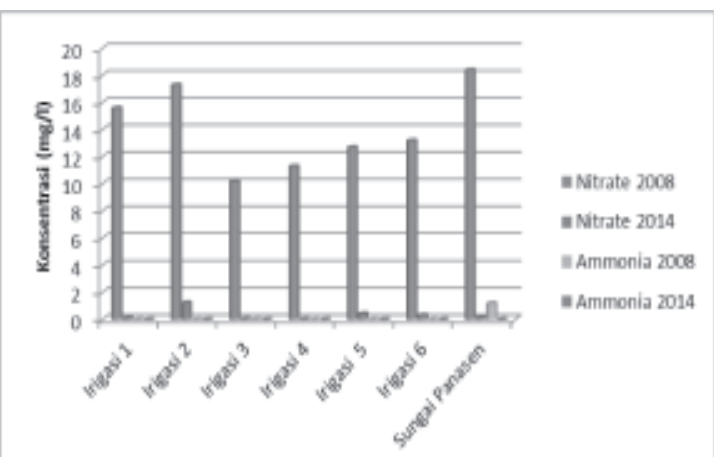

Gambar 5.

Konsentrasi Nitrat, Ammonia di Outlet Saluran Irigasi dan Sungai Bagian Selatan Danau Tondano (Data Tahun 2008 dan 2014)

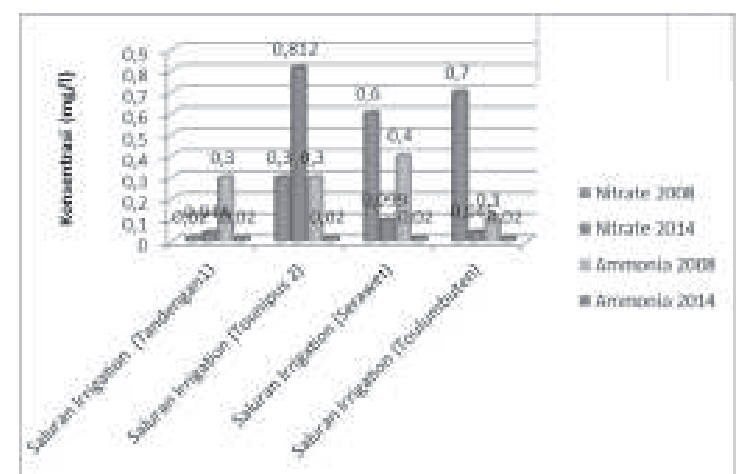

Gambar 6.

Konsentrasi Nitrat, Ammonia di Outlet Saluran Irigasi Bagian Timur Danau Tondano (Data Tahun 2008 dan 2014)

pengukuran tahun 2014 memiliki konsentrasi nitrat yang tinggi. Saat pengukuran dilakukan tanaman berada dalam pertumbuhan vegetatif aktif dan saat pemupukan sintetis dilakukan. Konsentrasi nitrat di outlet saluran irigasi tergantung pada kondisi lingkungan serta faktor-faktor penentu efisiensi pemupukan nitrogen.

Gambar 4, 5 dan 6 menunjukkan bahwa terjadi penurunan dan peningkatan konsentrasi residu nitrat, ammonia di outlet saluran irigasi dan sungai yang menjadi Inlet Danau Tondano bagian timur, bagian barat, dan bagian selatan kurun waktu 6 tahun (20082014). Salah satu penyebab terjadinya penurunan konsentrasi nitrat dan ammonia adalah pengurangan penggunaan pupuk sintetis. Saat ini mulai diupayakan pemanfaatan pupuk organik seperti bahan pupuk kompos dan jerami padi menjadi bahan baku untuk pembuatan pupuk organik. Walaupun belum semua areal penanaman mengaplikasikannya. Sebaliknya terjadi peningkatan konsentrasi nitrat berkaitan dengan teknik pemupukan. Hal tersebut berkorelasi dengan residu nitrogen di outlet saluran irigasi dan perairan di Daerah Aliran Sungai Tondano.

\section{Simpulan dan Saran}

1. Distribusi spasial nitrogen total konsentrasi tinggi terdapat di outlet sungai dan outlet saluran irigasi. Distribusi spasial nitrat di permukaan Danau Tondano terkonsentrsai di outlet danau, dan distribusi spasial ammonia di permukaaan Danau Tondano, menyebar secara merata dan lebih banyak terkonsentrasi di outlet sungai yang menjadi inlet Danau Tondano.

2. Secara temporal konsentrasi nitrat dan ammonia di Daerah Tangkapan Air (DTA) Danau Tondano berfluktuasi mengikuti aktivitas pemupukan, kondisi lingkungan serta faktorfaktor penentu efisiensi pemupukan nitrogen.

\section{Daftar Pustaka}

Asdak, C, 2004, Hidrologi dan Pengelolaan Daerah Aliran Sungai, Gadjah Mada University Press, Yogyakarta.

Arthana, I Wayan. 2006. Studi Kualitas Air Danau Beratan, Buyan dan Tamblingan di Bedugul, Bali. Jurnal Ilmu Lingkungan Ecotrophic. Program Studi Ilmu Lingkungan, Program Pascasarjana, Universitas Udayana. Volume 1, Nomor 2 : 34-38. Denpasar.

APHA, 2005. Standard Methods For The Examination of Water and Waste Water, American public Health Association (APHA) 21 st edition. Method 10200H and 4500-NO2-B.

Cossey D. A., W. E. Thomason, R. W. Mullen, K. J. Wynn, C. W. Woolfolk, G. V. Johnson, and W. R. Raun, 2002, Relationship Between Ammonium and Nitrate in Wheat Plant Tissue and Estimated Nitrogen Loss, Journal of Plant Nutrition 25 (7): 1430-1431 
Einsle, O; P.M.H Kroneck, 2004. Structural Basiss of Denitrification, Journal Biol.Chem Vol 385: 875876.

Elmi, A.A, C. Madramootoo, M. Egeh and C. Hamel, 2004. Water and Fertilizer Nitrogen Management to Minimize Nitrate Pollution From a Cropped Soin in South Western Quebee, Canada, Journal of Water, Air, and Soil Pollution 151: $117-134$

JICA, 2001, The Study on Critical Land and Protection Forest Rehabilitation at Tondano Watershed in Republik of Indonesia, Vol I, Main Report, Nippon Koei Co, Ltd and Kokusai Kogyo Co, Ltd.

JICA, 2001, The Study on Critical Land and Protection Forest Rehabilitation at Tondano Watershed in Republik of Indonesia, Vol II, Appendices (1/2) Nippon Koei Co, Ltd and Kokusai Kogyo Co, Ltd.

KLH, 2001. Peraturan Pemerintah Nomor 82 tahun 2001 tanggal 14 Desember 2001 tentang Pengelolaan Kualitas Air dan Pengendalian PencemaranAir (Kelas II).

Luntungan, J.N. 2014. Dinamika Spasial Penggunaan Lahan Pertanian Berdasarkan Citra Penginderaan Jauh, Tinjauan Dalam Rangka Menuju Pertanian Lestari Di Daerah Aliran
Sungai (DAS) Noongan dan Panasen Kabupaten Minahasa Provinsi Sulawesi Utara (Disertasi). Program Pasca Sarjana Fakultas Geografi Universitas Gadjah Mada, Yogyakarta.

Manahan, S.E, 2005, Environmental Chemistry ( $8^{\text {th }}$ edition), Florida USA. CRC Press LLC,

Palimbani, 2007. Mengenal Pupuk Urea, dalam internet http://pusri.wordpress.com, 1-2-2011.

Wantasen, S, 2012. Sebaran Spasial Ekologi Nitrogen di Danau Tondano Provinsi Sulawesi Utara (Disertasi), Sekolah Pascasarjana Universitas Gadjah Mada, Yogyakarta.

Wiederholt R and B. Johnson, 2005. Nitrogen Behavior in the Environment, dalam internet http://www.ag.ndsu.edu/19-1- 2007.

Yoshida, S. 1981. Fundamentals of Rice Crop Science, IRRI. Manila.

Wantasen, S; Sudarmadji; R.R.H. Rumende; J.L. Rantung, 2014. Study of Residual Nitrogen Fertilizer in Outlet of Paddy Irrigation in Tondano Watershed North Sulawesi, International Conference on Ecohydrology (ICE) in Conjunction with the 22nd Meeting of IHP Regional Steering Committee (RSC) for South Asia and Pacific 2014 November 10 - 12, 2014, Yogyakarta - Indonesia International Conference on Ecohydrology (ICE). 